DOI: 10.2478/aussoc-2020-0003

\title{
Everything Changes... More or Less. Opinions about the Post-Pandemic World among Ethnic Hungarians from Transylvania (Romania)
}

\author{
Laura NISTOR \\ Sapientia Hungarian University of Transylvania, Cluj-Napoca, Romania \\ nistorlaura@uni.sapientia.ro \\ Orsolya GERGELY \\ Sapientia Hungarian University of Transylvania, Cluj-Napoca, Romania \\ gergelyorsolya@uni.sapientia.o \\ Ágnes SÁNTHA \\ Sapientia Hungarian University of Transylvania, Cluj-Napoca, Romania \\ santhaagnes@ms.sapientia.ro \\ Balázs TELEGDY \\ Sapientia Hungarian University of Transylvania, Cluj-Napoca, Romania \\ telegdybalazs@uni.sapientia.ro
}

\begin{abstract}
The analysis presents some of the results of an online survey regarding the COVID-19 pandemic, which was undertaken among ethnic Hungarians from Transylvania. The survey was based on a convenience sample and was realized between 16 and 26 April 2020, so during a specific period of the lockdown. Among others, the questionnaire asked the respondents about the degree in which the post-pandemic world would change. The answers to the question show that nearly three quarters of the respondents think that the world will not change at all or it will suffer only minor changes. Those who are more prone towards seeing a totally or a majorly changed world are in a minority. We assume that this situation could reflect a wishful thinking in front of an uncertain context. The regression analysis showed that respondents' opinion regarding the change can be only marginally predicted by the selected independent variables. Men, those holding materialistic values, are significantly less convinced that the world will suffer major/total changes. On the other hand, trust in several institutions raises the odds of formulating the opinion that the postpandemic world will be considerably changed.
\end{abstract}

Keywords: COVID-19, convenience sample, Transylvania, openness to change 


\title{
Introduction
}

\begin{abstract}
"I'm afraid of everything that the contagion can change. Of discovering that the structure holding up civilisations I know it is nothing but a house of cards. I'm afraid of annihilation, but also of its opposite: that fear will eventually pass without leaving any trace of change behind.” (Giordano, 2020)
\end{abstract}

The COVID-19 pandemic has generated a series of previously unknown experiences: the lockdown, including the closing of schools, full- or part-time working from home settings associated with the fear of an unknown enemy have turned life upside down throughout the world. Such events legitimate to talk about a social change and, indeed, scholars agree that the pandemic will result in some sort of changes (see the summary of Nistor et al. 2020). Some of these changes are already occurring (online teaching, the transformation of the office, closing of national borders, etc.); however, we can only speculate if such changes mean a permanent societal transformation, or, as the pandemic ends, life will return to its normal course. According to the words of Giordano (2020), what is sure for now is that normality is suspended, but nobody knows for how much time. In such uncertain times, not only experts are those who try to elucidate how the post-pandemic world will look like, but also everyday discussions gravitate around this topic.

How will the world be after this unique worldwide event? Among many other questions, this was one that we addressed to the respondents of an online survey which investigated the ways in which ethnic Hungarians from Transylvania confronted with the pandemic and with the associated lockdown. The survey was realized between 16 and 26 April 2020, i.e. in a period when Romania was in lockdown. In that period, Romanian citizens, including ethnic Hungarians from Transylvania, were highly aware of the health risks of the SARS-CoV-2 virus, respected the measures and constraints imposed by the authorities, and speculated about a possible date when relaxation measures are going to take place. Several surveys show that once the lockdown ended (as of 15 May 2020), citizens became more anxious and they started to question not only the measures taken by the authorities but also the existence of the virus itself (e.g. IRES 2020). Possibly, our respondents' view on the post-pandemic world could have changed since April 2020 and, consequently, the present analysis should be read as a purely explorative endeavour which looks at the future from a specific moment of the past.

After a short review of a sort of a pandemic-related social change and of the individual determinants of openness to change/resistance to change, we will present the methodology of the survey and then the results of an ordinal logistic regression analysis, which tried to elucidate those individual-level variables which could shape respondents' view on the post-pandemic world. 


\section{Social Change in the Context of the COVID-19 Pandemic}

Social change is one of the basic concepts of sociology, so it is not a surprise that one can find very many definitions of it. ${ }^{1}$ Some of these definitions are very general, while others try to accentuate some measurable patterns of social change. Johnson (1960: 626) describes social change as "the change in the structure of a social system; what have been stable or relatively unchanging changes”. In this approach, change is an abstract construct, and it refers to "some” new patterns of social systems. Vago's (1999) approach of social change is, however, more specific as it defines change as an intentional or unintentional, qualitative or quantitative transformation of the social system. In the author's view, change can be characterized (and measured) by the following patterns: identity (i.e. what is changed in the social phenomenon, i.e. attitudes, social practices, etc.); level of change (e.g. micro-, meso-, or macro-level changes); duration (is the change occurring only in the short-term or is it a longterm transformation?); direction (does the change result in decline, development, or progress?); magnitude (marginal, major, evolutionary changes), and rate (is the change slow, fast, continuous, etc.?).

Far from being exhaustive, we mention that one of the earliest approaches on social change is that of Tönnies (1887/1983): the author described a major social change, i.e. the transformation of the traditional society (Gemeinschaft) into modern society (Gesellschaft), and focused on several specific manifestations of the social organizations and practices, such as the dissolution of community ties, the replacement of religious worldview by rationality, the widespread of urban livelihood and industrial production, etc. The transformation of modern societies into postmodern societies is another example of major social change. As Lyotard (1984) contends, postmodernity is an era of constant change: it refers to a condition where former positivist thinking is continuously questioned and meta-narratives become outdated. The author emphasizes also that much of the postmodern condition is due to technology and artificial intelligence: technology becomes widespread and allows the acquisition of knowledge and information by virtually everyone. Such transformations were then described as information society (i.e. a society where the production is based on information goods (Masuda 1981) and where, due to the availability of information and communication technologies, individuals will adopt new practices in virtually every domain of their lives) or network society (Van Dijk 2006). These societal changes were approached also from the viewpoint of the transformation of values. Inglehart's $(1977,1990)$ thesis about the value shift from materialist (i.e. surviving) to postmaterialist (e.g. self-expression) values reveals a cultural change which occurs on the basis of a series of societal transformations in terms of institutions and social

1 The works of Boudon (1991), Sztompka (1993), Sanderson (2007), and Vago (1999) are illustrative for the many approaches on social change. 
practices (e.g. economic prosperity, absence of war, spread of the service economy, rising level of education, etc.).

Others approached social change through specific sound concepts. Fukuyama (1992) referred to "the end of history", a concept through which the author contended that social change can be linked not only to long-term phenomena of transformation but also to specific events. Thus, the fall of the Berlin Wall marks the end of the history as such and signals the spread of liberal democracy. McDonaldization is quoted by Ritzer (1993) as a metaphor for globalization, i.e. a major macro-social change resulting in the homogenization of life (e.g. production, consumption, cultural norms, etc.). Risk society is another famous term (Beck 1992), which refers to a society that is continuously dealing with hazards as by-products and obsolete conditions of the modern industry, technology, and globalization.

Such major works describe various facets of social change: in each of them, social change represents a major social phenomenon which is linked to substantial transformations, whether we are speaking of knowledge production and distribution, industrial production, the organizations of social and political institutions, etc. As we have summarized elsewhere (Nistor et al. 2020), since the beginning of the pandemic, several international think tanks have been preoccupied to find answers to the question whether the pandemic will result in social change. Experts agree that the pandemic will result in some sort of change; however, there is little data on approaching the change in Vago's (1999) terms, i.e. in the form of measurable, pivotal elements of change. Thus, there is much speculation about whether these changes will occur only on the short term or will result in long-term transformation, whether they will mark the end of an era or will be only short-term manifestations of specific practices and attitudes. Some of the possible changes are already taking place no matter we are speaking about the strategies and fears of adaptations to a previously unknown virus and disease, social distancing, the wearing of face masks, online teaching and working arrangements, travel-related re-arrangements, etc. It remains, however, a question if these changes will be part of our lives in the post-pandemic world as well.

Since the pandemic is far from the end, researchers base their opinions on previous events (e.g. the 2008 economic crisis) or on those already occurring changes which could shape the nature of future transformations. One of the frequently invoked changes is the "rebirth of the nation-state". As Allen et al. (2020) contend, the pandemic has resulted in specific national-level approaches, but much of these were coherent in the sense that states temporarily closed their borders in order to stop the spread of the virus through international travels. In this sense, the pandemic can be interpreted as the crisis of globalization, and so it allows to envision a world in which national boundaries, national solutions will reborn. The authors also emphasize that many of the national-level decisions are questionable in their democratic nature, so it is even possible that the pandemic will result in 
the birth of new democratic forces, in the re-accentuation of the human rights, etc. The authors of Politico (2020) consider that the pandemic will "end the world as we know it". Among the many elements of change, the thinkers invited to debate on the post-pandemic future consider the following: the end of traditional workplace (i.e. the spread of remote working and home office settings); the change of the eating out practice in the context of consumers' lack of trust and social distancing initiatives; the reconsideration of the importance of sustainable production and consumption practices (i.e. local food, local commerce); the accentuated spread of the online consumption; changes in transportation (more bikes, less air travel, the reconsideration of health and safety in the case of airports, urban transportation, etc.); the recognition of the importance of health experts, online services, etc.

Dartnell (2020) also considers that the pandemic "will certainly change the world". The author sees the possible long-term changes mostly in connection with the workplace: the classic office, the regular 9-17 working schedule will be replaced by more flexible working arrangements and home office practices. These then will result in less harsh urban traffic but also in the drop of prices of the urban properties since remotely working employees will be tempted to move in the much comfortable and liveable suburbs, but the author is quite reserved in what regards the possible positive environmental impact of the pandemic. However, others, such as Monbiot (2020), Lányi (2020), etc., see a good opportunity in the pandemic in reversing the negative environmental effects of the current socio-economic arrangements: they argue that once the pandemic ends we must come out from our comfortable bubbles and see the multiple connections between climate change - food supplies - and diseases, and, consequently, both individuals and institutions must act in order to reverse climate change.

Zografos (2020) argues that the pandemic showed some critical problems and vulnerable groups: e.g. the exploitation of migrant workers and their unhealthy living arrangements, the need to invest in medical care, gender inequalities (e.g. mostly women are the care workers in hospitals and other care institutions). Therefore, the post-pandemic world will need to achieve social changes that enhance solidarity, end exploitation and structures of privilege. The same needs are accentuated by the UN (2020) as well.

Friedrich Naumann Foundation's (2020) essay contest in the Czech Republic asked youngsters to envision the post-pandemic world. The laureates of the contest expressed their doubts whether the changes will bring long-term transformations; however, they agreed that such transformations will impact the economic life (crisis, lower wages, unemployment) and social values (the re-emergence of the importance of family, personal development, education, and health). They also expressed their hope that the post-pandemic world would result in more environmentally-friendly behaviours as the lockdown showed the importance of spending time in natural surroundings. 
Other authors are less enthusiastic regarding the post-pandemic changes or see the post-pandemic world in a negative way. Kiss (2020) considers that once the pandemic ends the world will go on as usual. The author bases his argument on the previous 2008 economic crisis, which, although showed the vulnerability of the capitalist system, did not change the structuring and functioning of the capitalist and profit-centred economic arrangements. Walker et al. (2020) assess that the post-pandemic world can create new inequalities between citizens both in terms of geopolitical locations and in terms of their immunity (e.g. those who are not infected, who are immune, or who are infected), the case of the so-called "immunity passports" being illustrative in this respect.

Only a short review of these possible scenarios suggests that there is no clear agreement about the post-pandemic world, and it is debatable whether there will be changes and, if yes, whether these transformations will be for the better or, on the contrary, will deepen current societal problems. Thus, for now, it remains largely at the level of individuals and of their experiences how they currently feel about the post-pandemic world. Consequently, we can speculate about the role of several individual-level characteristics which can shape people's view of the postpandemic future.

\section{Openness to Change vs. Resistance to Change}

Change always results is some sort of stress and uncertainty; there are opinions that resistance to change is a natural reaction of mankind (Kotter 1995). Studies on human values showed a more nuanced picture. For instance, Schwartz's (1992) theory on basic human values describes ten universal, cross-culturally valid (i.e. pancultural) values: benevolence, universalism, self-direction, stimulation, hedonism, achievement, power, conformity, security, and tradition. These values can be found in each culture; however, individuals are not similar in the importance they give to the ten values, that is, there are specific axiological hierarchies between individuals which then might result in inter-cultural specificities. From the viewpoint of the topic of our analysis, two are particularly important of Schwartz's values: security (i.e. valuing the safety and stability of social contexts and of self, e.g. order, social security, risk avoidance, etc.) and stimulation (i.e. excitement, novelty, adventure, e.g. daring, exciting, adventurous life, etc.) (Schwartz 2003, Nistor-Iluț 2011). Obviously, people are not similar in the importance they give to security and stimulation, and, as far as values can "serve as criteria of choice between variants of actions" (Nistor-Iluț 2011: 336), it becomes obsolete to expect different attitudes towards the post-pandemic changes. Unfortunately, our survey did not measure any of Schwartz' values; however, the questionnaire included the classic Inglehartian 
index on materialist/postmaterialist value orientations, ${ }^{2}$ which allows to measure a linkage between the attitudes towards the post-pandemic changes and value orientation (Inglehart 1971, 1990; Inglehart-Abramson 1994). According to Inglehart and Baker (2000), postmaterialist, i.e. self-expression values, illustrate individuals' freedom and openness to economic and physical security (i.e. materialist values), wherefore we can presuppose a positive relationship between the degree of postpandemic change and the underlining values, i.e. those who give priority to survival values will envision no or little change, while those who give higher priority to posmaterialist values will envision a changing post-pandemic world.

Studies taking place in organizational settings showed a nuanced picture, assessing that individuals do not react similarly to changing situations: while some people are more comfortable with uncertainty, see in change an opportunity, and thus consider change as a form of challenge, others react negatively to the smallest transformations, they feel threatened, anxious and are reluctant to changes (Wanberg-Banas 2000). Thus, there were revealed two contradictory profiles: those who are open to change (i.e. are willing to support change and have a positive attitude towards it and those who are resistant to change (Hofstede 1980, Wanberg-Banas 2000).

Besides the role of the values, there were revealed specific factors which shape people's attitudes to change. The cognitive adaptation theory contends that openness to change is dependent upon individuals' self-esteem, optimism, and perceived control (Taylor-Brown, 1988), that is, those who have high self-esteem are more optimistic about the future and think that they can have some sort of control over the change, so they are more open towards transformations. Others emphasize that, besides the individual-level specificities, there are organizational contexts which may favour/hinder people's attitude towards change. Thus, it was revealed that trust can be an important structuring force: those who trust their superiors and colleagues are more open towards change (Chawla-Kelloway 2004, Grama-Todericiu 2016). Job/financial insecurity is also important: those who feel that organizational change will have a negative impact on their employee status are reluctant to change (Iverson 1996, Dent-Galloway Goldberg 1999, ChawlaKelloway 2004). Those who feel informed about the change or are participating in the process of change are more open towards it, and so are those who report changespecific self-efficacy (Wanberg-Banas 2000).

It was also shown that besides values people's reaction to change is two-dimensional: attitudinal and behavioural (Chawla-Kelloway 2004), that is, people can have a psychological acceptance/rejection towards change, and they can also manifest

2 Respondents are asked to select which of the following are the most important for them: a) Maintaining the order of nation; b) Giving the people more say in important government decisions; c) Fighting rising process; d) Protecting the freedom of speech. Then, they are asked to indicate which out of the four options is the second most important for them. Then, respondents are grouped as follows: materialistic $(a+c)$, post-materialistic $(b+d)$, and mixed (other combinations). 
specific behaviours that reflect their attitudes to change. In our study, we examined only the attitudinal level, i.e. what the respondents' perception was about the postpandemic changes. Change was taken on an abstract level, and so respondents had to decide on a 1-4 scale the degree of change they assumed would happen in the world once the pandemic ends. Our respondents were ethnic Hungarians from Transylvania, Romania, i.e. from a context which is not particularly favourable for openness to change. Previous studies documented that, according to the Schwartz's values, Romanians' as well as Hungarians' most important value is security (i.e. to live in secure surroundings and the government to ensure their security), while stimulation (i.e. looking for new things, openness to adventures) ranks the last out of the ten values (Nistor-Ilut 2011). Other studies reported that Romania reveals a traditional, materialistic value structure (Voicu 2007). Gavreliuc (2011) shows that on the basis of the Hofstede cultural inventory Romania has low openness to change (it scores 30 on a 1-100 scale). Referring specifically to ethnic Hungarians in Transylvania, various studies have shown that even the younger exponents of this population attach high importance to the values of security and stability (e.g. Kiss et al. 2008).

Our study was an explorative endeavour in the sense that we did not formulate hypotheses. However, on the basis of the aforementioned literature, we presupposed some specific results and raised the question as to whether the majority of the respondents will envisage a post-pandemic world in which only minor changes will occur or one which will not be changed at all. We also envisioned that those who show postmaterialistic values are economically better-off, feel that they have some sort of control over changes (i.e. have financial provisions), have greater trust in institutions and others, show change-related self-efficacy (i.e. better health, economic provisions, better information-processing ability), and will be more openminded about change.

In terms of the literature on values, we also left room for the question as to whether younger individuals (Vaillant 2002, Robinson, 2013), male respondents (Hinz et al. 2002, Robinson 2013), ${ }^{3}$ those living in urban settings and have higher education (i.e. it may enhance self-efficacy and control over change) will consider that the world will suffer substantial changes.

\section{Methodology}

The analysis is based on the results of a survey undertaken among ethnic Hungarians from Transylvania, Romania, between 16 and 26 of April 2020. This was a specific period of the lockdown, meaning that the country was in an emergency state, leaving one's home was permitted only for several reasons (e.g. work, grocery

3 The data on the role of gender, openness to change, and security are rather inconsistent or show limited differences (Schwartz-Rubel 2005). 
shopping, medical assistance), schools were closed, and an important part of the population was working from home. It was unclear when relaxing measures were going to happen, so insecurity was a general feeling. Thus, survey results are relevant considering only that specific period. Since then, many different emotions have come to the surface and a great number of events succeeded one another, and thus further studies on populations' attitudes towards the pandemic resulted in different outcomes (e.g. IRES 2020). Besides the specific timing of our study, another specificity refers to the ways in which data were collected. We did not use probability sampling, and so the survey was based on convenience sampling and the questionnaire was distributed online, mostly through social media and other platforms (e.g. the website of our university, some media platforms, etc.). This means that the results cannot be generalized to the entire population of Hungarian ethnicity living in Transylvania, so they reflect only the opinion of those who selfselected themselves to respond to the online questionnaire.

The questionnaire was fully completed by 1,269 respondents. Two-thirds $(74 \%)$ of the respondents are from urban settings, and 58\% of them are from Covasna and Harghita counties (i.e. the two counties which concentrate the majority of the ethnic Hungarian population living in Transylvania), while those having a university degree $(66 \%)$ and women $(80 \%)$ were overrepresented in the sample. The average age of the respondents is 37 years old. Half of the respondents are married, one quarter of them lives with a partner, and another quarter are single. $56 \%$ of the respondents have children, and two-thirds of the parents have children below 18 years of age. The economic status of the respondents shows that $66 \%$ are employed or are entrepreneurs, $15 \%$ are students, $16 \%$ are inactive, and the remaining part of the respondents are day workers or have part-time jobs. Half of the respondents have a monthly income between RON 2,000 and 4,000 (approx. 420-810 EUR). All in all, it can be stated that the respondents resemble a middle-class profile: urban respondents with university degrees and privileged economic situation, mostly with children. These patterns coincide also with the general profile of active Internet users, which is not a surprise as being an active Internet user is usually the sine qua non criterion for answering online surveys (Lefever et al. 2007).

The questionnaire addressed different issues in connection with the pandemic: e.g. how the respondents spent their time during the lockdown; their participation in home office activities and opinions about home office; attitudes towards the online school/home schooling; division of domestic labour during lockdown; trust in people and institutions; economic problems and arrangements; subjective health, health understanding; challenges of the lockdown; fears concerning the pandemic and other risks; opinions about the forthcoming world, etc.

The analysis below presents the results of the survey regarding this last question, i.e. how respondents see the post-pandemic world, more specifically how they appreciate the magnitude of change the world will suffer. Do they think that the 
world will remain the same, will change drastically, or will there be some sort of minor/major changes? Thus, the question investigated the magnitude of change (Vago 1999) on a $1-4$ scale ( 1 - the world will remain the same, i.e. no change at all; $2-$ the majority of things will remain the same, i.e. minor change; 3 - the majority of things will change, i.e. major change; 4 - the world will change completely, i.e. total change).

As change was considered in an abstract sense, we presupposed that the answers might reflect not only what respondents know or think about the post-pandemic world but also how they would like the post-pandemic world to be (i.e. wishful thinking). On a very general level, we presupposed that those who were reluctant to changes or did not have resources (e.g. education, finance, self-efficacy, etc.) were more scared of a social change and they might project these fears onto the answers, preferring a world which would not change or would suffer only minor changes. On the contrary, those who are more open about changes in general or possess certain resources will be more open to changes. The question under research (i.e. the dependent variable) was asked in the context of a broader online questionnaire which dealt with other specific questions related to the pandemic. Thus, there is possibility for a multivariate analysis.

The dependent variable is an ordered variable, so we relied on ordinal logistic regression. We estimated two models: one which investigated the influence of several socio-demographic variables and a second one which added several other predictors to the first model, i.e. axiological orientation, self-efficacy, and trust.

The first model included only socio-demographic variables: age (categorical), gender (dummy), education (categorical), residence (dummy), presence of children (dummy), and income (measured with a proxy categorical variable). Regarding this last variable, we mention the following: instead of the declared income, we opted for the variable of whether respondents had financial provisions. This was motivated on the one hand by the relatively large number of missing responses to the question regarding last month's income and, on the other hand, by the fact that, on the basis of the cognitive adaptation theory (Taylor-Brown 1988), we considered the existence of provisions as a good indicator for the perceived control over change, i.e. those having financial provisions being more open about change since they have sufficient resources to avert the eventually negative outcomes of change. This option can be sustained by empirical data as well since there is a high multicollinearity between income and financial provisions.

Besides the socio-demographic variables, the second model included the following predictors: subjective health (categorical), ability of processing information related to the pandemic (dummy), ${ }^{4}$ value orientation (categorical), interpersonal trust (2-factor scores: i.e. trust in closely related people, trust in foreign people), and

4 Thus, having financial provisions (included in the first model), good subjective health, and the ability to process information regarding the pandemic (both included in the second model) were considered indicators of self-efficacy and personal control over change. 
institutional trust (4-factor scores: trust in repressive institutions, trust in public non-repressive institutions, trust in international organizations, trust in the media).

We measured change-related self-efficacy and control over change by three variables: having financial provisions, subjective health, and ability to process information related to the pandemic. Thus, we presupposed that financial resources as well as a good health condition and knowing one's way around the huge amount of information related to the pandemic are protective factors against change (cf. Wanberg-Banas 2000). Trust was introduced based on the rationale that those who perceive more social and institutional support might be more open to change (Iverson 1996; Wanberg-Banas 2000). Value orientation reflected the rationale that the attitude towards change may reflect value orientations, meaning that those who are oriented towards security will be less open to changes.

Albeit the selection of the variables was based on several considerations of the literature, we did not aim to rigorously test hypotheses. Our sole aim was to explore whether the selected variables have any influence in shaping respondents' attitudes towards the magnitude of post-pandemic change. Deciding not to test the hypotheses was also motivated by the already mentioned fact that the question of post-pandemic change is a very much open question: no one knows the nature of this change (the rate, the magnitude, etc.), and there are only speculations and individual interpretations. Thus, all we can do is to see whether any of the selected variables has a particular influence on the ways in which respondents' see the postpandemic world. Another argument for skipping the rigorous hypotheses and their testing is the nature of our sample: we work on a convenience, non-representative sample, which is not quite favourable for testing hypotheses. So, even if one finds significant or non-significant relations, they must be interpreted much more as indicative of further working hypothesis rather than the situation on the ground.

\section{Results of the Analysis}

Firstly, we present the descriptive statistics on the frequency of the responses to the question regarding the magnitude of change ("do not know" options were treated as missing values). The graph below shows that 1,210 out of the 1,269 respondents of the survey formulated an opinion about the question. The majority of them (i.e. $70 \%$ ) think that the pandemic will leave the world unchanged or will have only a minor impact on the world. As we mentioned before, we explored change in an abstract sense, so we do not know what change meant for the respondents. In any case, in seeing the post-pandemic world from a typical period of the lockdown (as of April 2020), when respondents experienced a lot of fear, anxiety, and new life arrangements, we may suspect that responses also reflect the wish for the re-arrangement of things, i.e. a kind of self-deceiving optimism (Krizan-Windschitl 2009). 


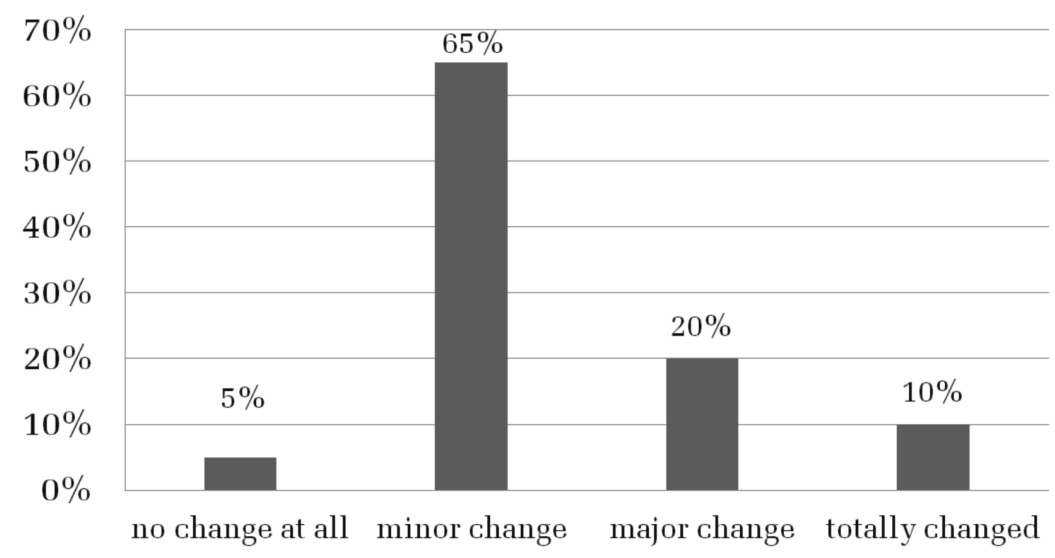

Figure 1. Opinions regarding the extent to which the world will change after the pandemic $(\mathrm{N}=1,210)$

As we mentioned elsewhere (Gergely et al. 2020, Nistor et al. 2020), bivariate analysis did not signal important differences. The youngest respondents (those below 25 years of age) were a little bit more prone than other age-groups to see a more changed world after the pandemic. That is, $36 \%$ of the respondents from the youngest age-groups thought the world would become completely changed or would suffer major changes, and this was the highest percentage of pro-change attitudes across the age-groups. With regard to gender, we found that women were more prone to see complete or major post-pandemic changes compared to men ( $31 \%$ vs. $20 \%$ ). In terms of education, the results showed that those with higher education were the most sceptical about changes (27\% vs. $33 \%$ in the case of those having medium-level education and $34 \%$ in the case of those with low education). Albeit not extraordinarily harsh, such differences are a bit surprising because (except the case of age-groups) they are against literature's considerations regarding openness to change.

Indeed, the fact that men and those with higher education levels are more sceptical about post-pandemic changes could signal a counter-intuitive tendency in the light of the literature. However, it can also be interpreted as a wishful thinking or, on the contrary, as a form of manifestation of fear as those who opt for a major or complete change might do this because they want the world to be better, more favourable for them (e.g. those with low levels of education, young people, or even women), while those who opt for only minor changes might do this because of their reluctance to change, their fear, or maybe their more sceptical attitudes. Unfortunately, these are only speculations, and more grounded responses could be traced only on the basis of further research. In any case, we were interested in seeing how the attitudes about the post-pandemic world will behave in a multivariate analysis. For this purpose, we constructed an ordinal logistic regression model. In this model, the dependent variable was represented by the degree of change, while independent variables were 
introduced based on the above mentioned considerations of the special literature in what concerns the determinants of the openness to change.

The following table summarizes the results of the ordinal logistic regression with beta estimates. Statistically significant effects according to the Wald test are marked with the * sign.

Table 1. Ordinal logistic regression on the opinions regarding the magnitude of post-pandemic change

\begin{tabular}{|c|c|c|}
\hline & Model 1 & Model 2 \\
\hline & Estimates & Estimates \\
\hline \multicolumn{3}{|l|}{ Age (reference: $55+$ ) } \\
\hline$>25$ & 0.102 & 0.013 \\
\hline $26-34$ & -0.647 & 0.184 \\
\hline $35-44$ & -0.168 & -0.200 \\
\hline $45-55$ & -0.264 & -0.240 \\
\hline Male & $-0.484 * *$ & $-0.647^{*}$ \\
\hline \multicolumn{3}{|l|}{ Education (reference: upper) } \\
\hline Low level & 0.263 & 0.323 \\
\hline Medium level & 0.156 & 0.124 \\
\hline \multicolumn{3}{|c|}{ Provisions (reference: large amount) } \\
\hline Without provisions & 0.182 & -0.105 \\
\hline Small amount & 0.262 & 0.237 \\
\hline Rural residence & -0.165 & -0.121 \\
\hline With children & 0.064 & -0.043 \\
\hline \multicolumn{3}{|l|}{$\begin{array}{l}\text { Subjective health (reference: } \\
\text { excellent) }\end{array}$} \\
\hline Acceptable & & 0.532 \\
\hline Good & & 0.090 \\
\hline Easily handles information & & 0.253 \\
\hline \multicolumn{3}{|l|}{ Values (reference: postmaterialist) } \\
\hline Materialist & & $-0.494^{*}$ \\
\hline \multicolumn{3}{|l|}{ Mixed } \\
\hline Interpersonal trust (in-group) & & -0.092 \\
\hline Interpersonal trust (out-group) & & -0.001 \\
\hline \multicolumn{3}{|l|}{ Institutional trust in: } \\
\hline Repressive institutions & & $0.175^{*}$ \\
\hline Public institutions & & $0.166^{*}$ \\
\hline International institutions & & -0.053 \\
\hline The media & & 0.046 \\
\hline & $\begin{array}{c}\mathrm{Chi}^{2}=19.347 ; \mathrm{df}=11, \\
\mathrm{p}<0.05 \\
\text { Nagelkerke } \mathrm{R}^{2}= \\
0.022\end{array}$ & $\begin{array}{c}\mathrm{Chi}^{2}=37.764 ; \mathrm{df}= \\
23, \mathrm{p}<0.05 \\
\text { Nagelkerke } \mathrm{R}^{2}= \\
0.066\end{array}$ \\
\hline
\end{tabular}

${ }^{*} \mathrm{p}<0.05,{ }^{* *} \mathrm{p}<0.005$ 
The results of the regression are quite frustrating: through the variables which we included in the model, we succeeded to explain only a very small part of the variations of the dependent variable. As the Nagelkerke $\mathrm{R}^{2}$ values show, the sociodemographic variables explain only $2.2 \%$ of the variance in the opinions regarding the magnitude of post-pandemic changes. As we added other variables (values, self-efficacy, various forms of trust), the explanatory value of the model became only slightly better, i.e. $6.6 \%$. As seen from the models, there are only three types of variables which seem to significantly determine the opinions regarding the post-pandemic changes. Compared to women, male respondents are significantly less predisposed to envision major or complete changes after the pandemic ends; compared to the reference category, the odds of male respondents of holding the opinion that the world would not suffer major changes after the pandemic ends are $\mathrm{e}^{-0.647}$, i.e. 0.52. Another variable which significantly influences the opinions on the post-pandemic change is axiological value orientation. Compared to those who have postmaterialistic value orientation, the respondents who hold materialistic values are significantly less predisposed to envision major changes. Several forms of trust also seem to have a significant influence: those who have higher levels of trust in repressive institutions (i.e. the army, the police, the judiciary system, etc.) as well as those who have greater trust in other public institutions (i.e. government, health, education institutions, etc.) are significantly more predisposed to envision major changes in the post-pandemic world.

We interpret the low explanatory power of the models together with the limited number of variables having significant influence on dependent variables on the basis of two facts. The first one is connected to the limitations of the convenience sample, which implies a set of self-selection biases: women were overrepresented in the survey, which can be an explanation for the gender-based differences in the rating of the magnitude of change; it could also happen that certain profiles (e.g. those who were more prone to see a world which would not suffer major changes) were more comfortable with the topic of the questionnaire and thus self-selected themselves for responding to the survey. This issue also raises the question as to whether or not we must be very strict in looking for variables with statistically significant influence. In a non-representative sample revealing several tendencies, often is enough in order to raise some further working hypotheses and in order to outline some possible answers. The second issue is linked to the ambiguity of the question regarding the post-pandemic world. As we have already shown in our short review, even experts and think tanks find difficult to formulate a concluding standpoint about the post-pandemic world. Thus, it is not a surprise that our respondents who are representative for a general public cannot be clearly structured in specific profiles regarding their opinions on the magnitude of change. That is, respondents expressed their opinions on an ambiguous question in a turbulent context, which practically does not have any clear point of reference. 
Once we look at the variables which have significant influence on the dependent variable, we can reveal both some easily explainable and some surprising results. Thus, it comes as not a surprise that those who have materialistic values are more prone to hold the opinion that the post-pandemic world will not suffer major changes. As already shown, the content of the materialistic value orientation presupposes the preference for survival values, for the security and stability of contexts (Inglehart 1990, Inglehart-Baker 2000). It was also shown in the literature that materialistic/postmaterialistic value orientation is quasi congruent with the conservation/openness dimension of Schwartz's value structure (Dobewall-Strack 2013). Therefore, it is perfectly plausible to expect that people with materialistic values are resistant to change in their attitudes and vice versa.

The literature regarding openness to change also showed (mostly on the basis of organizational contexts) that trust is a variable which enables openness to change. The rationale is that people who trust the organization and/or their colleagues are more convinced that the change will result in positive outcomes (e.g. ChawlaKelloway 2004, Grama-Todericiu 2016). More or less, our results seem to replicate these findings: those who have greater trust in specific types of institutions (i.e. repressive and public institutions) hold the opinion that the world will suffer major changes. A no-far-to-seek explanation for this result is that both repressive and public institutions have important duties in ensuring the crisis management of the pandemic. During the lockdown, people could witness the efficient power of the repressive institutions (i.e. controls, fines) as well as the overpowering and transformation of other public institutions (e.g. the government, health and educational institutions). It is, however, surprising that interpersonal trust or trust in other types in institutions, e.g. international institutions or the media, do not have a significant influence on the dependent variable. This finding possibly shows all those ambiguities which people have witnessed during the pandemic: neither fellow citizens nor the media or international institutions were able to deliver clear messages about the future, so trusting them was not enough for formulating a clear opinion on the post-pandemic changes.

Neither the subjective rating of personal health condition nor the capacity of handling COVID-19-related media information was able to significantly shape the opinions on the post-pandemic global change. We presupposed that such variables can be considered indicators of self-efficacy in the context of the pandemic-related changes, wherefore we can interpret the findings in the sense that in the context of an ambiguous change specific self-efficacy is not enough to/cannot explain the openness to change.

As already shown in our two-variable analysis (Gergely et al. 2020, Nistor et al. 2020), the majority of the socio-demographic variables do not make a major difference regarding the dependent variable. The sole significant influence comes from the part of gender: compared to women, male respondents are significantly less 
open towards change. Schwartz and Rubel (2005) concluded that the influence of gender on openness to change is rather inconsistent; so, along this line, the result is not surprising. However, there are also data which suggest that men are more openminded about change (Hinz et al. 2002, Robinson 2013), and in the light of such data our results are surprising. We could also interpret the results to mean that women's openness to change resembles in fact their fear from a major, overwhelming change. This may as well be an explanation as women (especially mothers) have already been overwhelmed by those changes which the pandemic has brought about: our results showed (Gergely et al. 2020, Nistor et al. 2020) that female respondents were responsible for the home schooling of children, and thus they experienced an overflow of domestic duties, thus facing an entirely new situation.

\section{Conclusions}

We started the analysis with a quotation from Italian author Paolo Giordano (2020). In his recent essays on the pandemic, the author expresses the view that he is afraid both of the changes the pandemic could bring about and of the possibility that the pandemic will leave the world unchanged. This is a view which expresses all those ambivalences which characterize the public discourse around the issue of postpandemic transformations. Some people hope that the pandemic will change for the better our behaviours and attitudes towards other people or towards the environment. Others, however, are afraid of any change and hope that the world will remain the same as before the pandemic and soon we will return to our comfortable bubbles.

In our analysis, we tried to empirically respond the question of how the postpandemic world will look like. For this purpose, we relied on a convenience-samplebased online questionnaire, which was applied among ethnic Hungarians from Transylvania, Romania, in a very specific period of the lockdown, i.e. in April 2020. The respondents were asked to answer the question regarding the magnitude of the changes the world would suffer once the pandemic ends. The results showed that the large majority of the respondents considered that the world would suffer only minor changes or would remain, after all, unchanged. Such opinions could be illustrative for wishful thinking, for self-deceiving optimism (Krizan-Windschitl 2009), meaning that in the context of turbulent, uncertain, and uncomfortable times people hope that such events will finally end, and the course of life will return to normal.

The attitudes about change can be researched also from the viewpoint of the openness to change/resistance to change perspective. In this respect, the literature has plenty of evidence which suggest that there are individual differences in people's openness to change. Much of this research emphasized the role of values (e.g. Shwartzian, Inglehartian), but the studies from organizational contexts also showed the importance of other factors, e.g. self-efficacy or trust. Following this 
line of research, we raised the question as to whether there are specific variables which can shape in a statistically significant way our respondents' opinions about the post-pandemic change. The results of the regression analysis showed that being male and holding materialistic values raise the odds of considering that the world will not suffer major changes, i.e. reluctance to change. On the other hand, trusting repressive and internal public institutions makes people to be more open towards change. While the influence of the axiological variables and that of trust resemble the considerations of the literature, the effect of gender is quite interesting. It can be explained by the overrepresentation of women among the respondents, but it might also signal that women who were overwhelmed by the many extra tasks (home schooling while working from home, extra domestic duties) the pandemic caused in their lives, and thus have already experienced the pandemic-related changes (Gergely et al. 2020; Nistor et al. 2020), showed a more realistic view on the post-pandemic world as well.

It is also interesting that those variables which could represent a protective factor (self-efficacy) in situations of risks and uncertainties (i.e. having financial provisions, good health and being able to process the pandemic-related information) proved to have no significant influence on the dependent variable. Obviously, such counterintuitive findings can be explained by the many biases of the non-representative convenience sampling, but they can also be a signal in the direction that the pandemic-related changes are so abstract and unconceivable that individual-level protective factors seem to be not enough in shaping the openness/reluctance to such a huge change.

\section{References}

Allen, John. et al. (2020). How the World Will Look Like after the Coronavirus Pandemic. Foreign Policy March 20, 2020 (https://foreignpolicy.com/2020/03/20/ world-order-after-coroanvirus-pandemic/).

Beck, Ulrich. 1992. Risk Society: Towards a New Modernity. London: Sage.

Boudon, Raymond. 1991. Theories of Social Change: A Critical Appraisal. Cambridge: Polity.

Chawla, Anuradha, Kelloway, E. Kevin. 2004. Predicting Openness and Commitment to Change. The Leadership and Organizational Development Journal 6(25): 485498.

Dartnell, Lewis. 2020. The COVID-19 Changes That Could Last Long-Term. BBC June 30 (https://www.bbc.com/future/article/20200629-which-lockdownchanges-are-here-to-stay).

Dent, Eric, Galloway Goldberg, Susan. 1999. Resistance to Change: A Limiting Perspective. The Journal of Applied Behavioral Science 35(1): 45-47. 
Dobewall, Henrik, Strack, Micha. 2013. Relationship of Inglehart's and Schwartz's Value Dimensions Revisited. International Journal of Psychology 49(4): 240-248. Fridrich Naumann Foundation. 2020. Life after Lockdown. What Will the World Look Like after the Coronavirus Pandemic (https://nf-europe.org/2020/06/15/lifeafter-lockdown-what-will-the-world-look-like-after-the-coronavirus-pandemic/).

Fukuyama, Francis. 1992. The End of History and the Last Man. New York: The Free Press.

Gavreliuc, Alin. 2011. Psihologie interculturală. Iaşi: Polirom.

Gergely, Orsolya, Nistor, Laura, Sántha, Ágnes, Telegdy, Balázs. 2020. COVID-19 járvánnyal kapcsolatos attitüdök és cselekvések. Online kérdöíves kutatás erdélyi magyarok körében. Research report.

Giordano, Paolo. 2020. How Contagion Works. London: W\&N Publisher.

Grama, Blanca, Todericiu, Ramona. 2016. Change, Resistance to Change and Organizational Cynicism. Studies in Business and Economics 11(3): 47-54.

Hinz, Andreas, Albani, Cornelia, Gießler, Anne, Brahler, Elmar. 2002. Welche Werte sindden Deutschen etwas wert? Ergebnisse einer reprasentativen Umfrage. Psychosozial 25: 21-30.

Hofstede, Geert. 1980. Culture's Consequences: International Differences in WorkRelated Values. Beverly Hills, CA: Sage.

Inglehart, Ronald. 1977. The Silent Revolution. Princeton: Princeton University Press.

1990. Culture Shift in Advanced Industrial Society. Princeton: Princeton University Press.

Inglehart, Ronald, Abramson, Paul. 1994. Economic Security and Value Change. The American Political Science Review 88(2): 336-354.

Inglehart, Ronald, Baker, Wayne. 2000. Modernization, Cultural Change, and the Persistence of Traditional Values. American Sociological Review 65(1): 19-51.

IRES. 2020. Bilanțul stării de urgență. Impactul COVID-19 asupra vieții românilor (https://ires.ro/uploads/articole/ires_bilantul-starii-de-urgenta-pentrupandemia-de-covid-19_13-14-mai-2020.pdf).

Iverson, Roderick D. 1996. Employee Acceptance of Organizational Change: The Role of Organizational Commitment. The International Journal of Human Resource Management 7(1): 122-149.

Johnson, Harry M. 1960. Sociology: A Systematic Introduction. London: Routledge \& Kegan Paul.

Kiss, Károly. 2020. Az „új károgók” tévednek: nem jön új világ, a globalizáció sem szorul vissza a vírustól. Valaszonline.hu April 9 (https://www.valaszonline. hu/2020/04/09/koronavirus-globalizacio-gazdasag-kiss-karoly-velemeny/). 
Kiss, Tamás, Barna, Gergő, Sólyom, Zsuzsa. 2008. Erdélyi magyar fiatalok 2008. Közvélemény-kutatás az erdélyi magyar fiatalok társadalmi helyzetéról és elvárásairól. Összehasonlító gyorsjelentés. Cluj-Napoca: ISPMN.

Kotter, John P. 1995. Leading Change: Why Transformation Efforts Fail. Harvard Business Review 73(2): 59-67.

Krizan, Zlatan, Windschitl, Paul D. 2009. Wishful Thinking about the Future. Does Desire Impact Optimism? Social and Personality Psychology Compass 3(3): 227243.

Lányi, András. 2020. Történelmünk legveszedelmesebb pillanatait éljük. Valaszonline.hu April 3 (https://www.valaszonline.hu/2020/04/03/koronavirusmagyarorszag-lanyi-andras-essze/).

Lefever, Samuel, Dal, Michael, Matthíasdótti, R. Ásrún. 2007. Online Data Collection in Academic Research: Advantages and Limitations. British Journal of Educational Technology 38(4): 574-582.

Lyotard, Jean-Francois. 1984. The Postmodern Condition: A Report on Knowledge. Minneapolis: The University of Minnesota Press.

Masuda, Yoneji. 1981. The Information Society as Post-Industrial Society. Washington: World Future Society.

Monbiot, George. 2020. Covid-19 is Nature's Wake-up Call to Complacent Civilization. The Guardian March 25 (https://www.theguardian.com/commentis free/2020/mar/25/covid-19-is-natures-wake-up-call-to-complacent-civilisation).

Nistor, Laura, Gergely, Orsolya, Sántha, Ágnes, Telegdy, Balázs. 2020. Erdélyi mindennapok egy világjárvány idején. Manuscript.

Nistor, Laura, Iluț, Petru. 2011. Inferring Us from Others - Turning Us towards Others. A Preliminary Comparative Analysis on Self-Transcendence Values in Hungary and Romania. Proceedings of the International Conference European, National and Regional Identity, 24-26 March, 2011, Oradea. Oradea: Editura Universității din Oradea. 335-366.

Politico. 2020. The World after Coronavirus. Politico April 29 (https://www.politico. eu/article/the-world-after-coronavirus-crisis-society-culture-economy/).

Ritzer, George. 1993. The McDonaldization of Society. Thousand Oaks, CA: Pine Forge Press.

Robinson, Oliver C. 2013. Values and Age: Findings from Two Cohorts of the European Social Survey. European Journal of Ageing 10: 11-23.

Sanderson, Stephen K. 2007. Social Change. In: Bryant, C. D., Peck, D. L. (eds.), 21 $1^{\text {st }}$-Century Sociology: A Reference Handbook. Vol. 1. Thousand Oaks, CA: Sage. 560-568.

Schwartz, Shalom H. 1992. Universals in the Content and Structures of Values: Theoretical Advances and Empirical Tests in 20 Countries. In: Zanna, M. P. (ed.), Advances in Experimental Social Psychology (vol. 1.). Orlando: Academic Press. 1-65. 
2003. A Proposal for Measuring Value Orientations across Nations. In: Questionnaire Development Report of the European Social Survey. Chapter 7: 259-319.

Schwartz, Shalom H., Rubel, Tammy. 2005. Sex Differences in Value Priorities. Cross-Cultural and Multimethod Studies. Journal of Personality and Social Psychology 89: 1010-1028.

Sztompka, Piotr. 1993. The Sociology of Social Change. Oxford: Blackwell Publishers.

Taylor, Shelley E., Brown, Jonathon D. 1988. Illusion and Well-Being: A Social Psychological Perspective on Mental Health. Psychological Bulletin 103: 193210.

Tönnies, Ferdinand. 1887/1983. Közösség és társadalom. Budapest: Gondolat.

UN (United Nations). 2020. The Social Impact of COVID-19 (https://www.un.org/ development/desa/dspd/2020/04/social-impact-of-covid-19/).

Vago, Steven. 1999. Social Change. New York: Prentice Hall.

Vaillant, George E. 2002. Ageing Well. Boston: Little, Brown.

van Dijk, Jan. 2006. The Network Society: Social Aspects of New Media. London: Sage.

Voicu, Bogdan. 2007. Între tradiție şi postmodernitate? O dinamică a orientărilor de valoare în România. In: Voicu, B., Voicu, M. (eds.), Valori ale românilor 19932006. Iaşi: Institutul European. 271-320.

Walker, Ben, Bednarek, Rebecca, Bridgman, Todd, Daellenbach, Urs. 2020. Creating New Social Divides: How Coronavirus is Reshaping How We See Ourselves and the World around Us. The Conversation, May 4 (https://theconversation. com/creating-new-social-divides-how-coronavirus-is-reshaping-how-we-seeourselves-and-the-world-around-us-137485).

Wanberg, Connie R., Banas, Joseph T. 2000. Predictors and Outcomes of Openness to Change in a Reorganizing Workplace. Journal of Applies Psychology 85(1): 132-142.

Zogrofas, Christos. 2020. COVID Recovery and Radical Social Change. The Ecologist. July 7 (https://theecologist.org/2020/jul/07/covid-recovery-and-radical-socialchange). 